\title{
ANALISIS BENTUK GHARAR DALAM TRANSAKSI EKONOMI
}

\author{
Nadratuzzaman Hosen \\ Fakultas Syariah dan Hukum Jakarta \\ Jl. Ir. H. Juanda 95, Ciputat, Jakarta.
}

\begin{abstract}
Abstrak: Lembaga keuangan konvensional banyak mengandung unsur gharar yang jelas telah dilarang dalam syariat Islam. Islam memiliki batasan yang tegas terhadap berbagai transaksi ekonomi, sehingga jelas mana yang dilarang atau tidak dilarang. Nilai-nilai keadilan merupakan hal utama yang menjadi prinsip pokok untuk melandasi kegiatan ekonomi, sehingga merasa teraniaya oleh pihak yang lain.
\end{abstract}

Kata Kunci: Gharar, keadilan, transaksi ekonomi.

\section{Pendahuluan}

Islam sebagai suatu agama tidak hanya mengatur ummatnya untuk selalu melakukan ibadah yang sifatnya ritual, yang merupakan bentuk penghambaan diri kepada Allah Swt bersifat vertikal. Tetapi, Islam memberikan aturan yang lebih luas dan komprehensif. Ibadah yang dilakukan oleh ummat Islam dapat pula bersifat horizontal, yaitu ibadah yang dilakukan didasarkan atas penciptaan hubungan yang terjadi pada lingkungan sosial, ekonomi dan politik.

Bagi setiap individu ummat Islam diwajibkan untuk melakukan pencitraan positif terhadap dirinya, orang lain, serta lingkungannya. Sehingga masing-masing individu bertanggungjawab atas kondisi dan situasi yang mengelilinginya. Keberadaan lingkungan sosial yang baik dan damai, kondisi ekonomi masyarakat yang sejahtera, dan situasi politik yang aman merupakan bagian dari ibadah yang dapat dilakukan oleh ummat Islam 
yang merupakan bentuk penghambaan kepada Allah Swt.

Salah satu ibadah tersebut adalah menciptakan kesejahteraan masyarakat dengan melakukan kegiatan ekonomi. Urgensi ekonomi tidak dapat diabaikan atau dipandang sebelah mata. Kegiatan ekonomi memegang peranan vital untuk menciptakan masyarakat yang sejahtera, adil dan makmur.

Islam mengajarkan dalam sistem ekonomi ummatnya, didasarkan pada nilai-nilai keadilan yang harus ditegakkan, dan menjadi prinsip pokok untuk melakukan kegiatan ekonomi. Setiap kegiatan ekonomi harus mengandung unsur manfaat serta tidak melakukan penganiayaan terhadap dirinya dan orang lain, sehingga kegiatan ekonomi dapat menciptakan kesejahteraan masyarakat secara merata.

Melakukan kegiatan ekonomi tidak diperbolehkan dengan melakukan penipuan, perjudian, pemaksaan ataupun mengambil hak milik orang lain dengan cara-cara bathil.

\section{Pengertian}

Arti dalam bahasa arab gharar adalah al-khathr; pertaruhan, majhul alaqibah; tidak jelas hasilnya, ataupun dapat juga diartikan sebagai almukhatharah; pertaruhan dan al-jahalah; ketidakjelasan. Gharar merupakan bentuk keraguan, tipuan, atau tindakan yang bertujuan untuk merugikan orang lain.

Di lihat dari beberapa arti kata tersebut, yang dimaksud dengan gharar dapat diartikan sebagai semua bentuk jual beli yang didalamnya mengandung unsur-unsur ketidakjelasan, pertaruhan atau perjudian. Dari semuanya mengakibatkan atas hasil yang tidak pasti terhadap hak dan kewajiban dalam suatu transaksi/jual beli.

Secara istilah fiqh, gharar adalah hal ketidaktahuan terhadap akibat suatu perkara, kejadian/ peristiwa dalam transaksi perdagangan atau jual beli, atau ketidakjelasan antara baik dengan buruknya.

Menurut madzhab syafi'i, gharar adalah segala sesuatu yang akibatnya tersembunyi dari pandangan dan sesuatu yang dapat memberikan akibat yang tidak diharapkan/ akibat yang menakutkan. Sedang Ibnu Qoyyim berkata bahwa gharar adalah sesuatu yang tidak dapat diukur 
penerimaannya baik barang tersebut ada ataupun tidak ada, seperti menjual kuda liar yang belum tentu bisa di tangkap meskipun kuda tersebut wujudnya ada dan kelihatan.

Imam al-Qarafi mengemukakan bahwa gharar adalah suatu akad yang tidak diketahui dengan tegas apakah efek akad terlaksana atau tidak. Begitu juga yang disampaikan Imam as-Sarakhsi serta Ibnu Taimiyah yang memandang gharar dari segi adanya ketidakpastian akibat yang timbul dari suatu akad. Sementara Ibnu Hazm melihat gharar dari segi ketidaktahuan salah satu pihak yang berakad tentang apa yang menjadi objek akad tersebut.

\section{Hukum Gharar}

Dasar pengambilan hukum atas segala sesuatu dalam syariat Islam harus jelas bentuk dan kriterianya, sehingga penetapannya akan mendapatkan suatu kepastian untuk menempatkan pada tingkatan boleh atau tidaknya untuk dilakukan, dan dapat dijadikan sandaran hukum.

Sudah jelas bahwa hukum terhadap sesuatu didasarkan atas hasil dari persepsi tentang sesuatu tersebut. Sedetail apa pengetahuan kita terhadap berbagai hal yang berkaitan dengan gharar, akan menentukan kedetailan kita dalam mendudukkan masalah berbagai transaksi yang dianggap sebagai bentuk transaksi gharar dan mampu untuk menjelaskan tentang hukumhukumnya, serta menetapkan berbagai alternatif pengganti dari transaksitransaksi yang disyariatkan.

Ibnu Taimiyah menjelaskan bahwa pelarangan terhadap transaksi gharar didasarkan kepada larangan Allah Swt atas pengambilan harta/ hak milik orang lain dengan cara yang tidak dibenarkan (bathil). Menurut Ibnu Taimiyah di dalam gharar terdapat unsur memakan harta orang lain dengan cara bathil. Dalam hal ini Ibnu Taimiyah menyandarkan pada firman Allah Swt, yaitu:

Dan janganlah sebagian kamu memakan harta sebagian yang lain diantara kamu dengan jalan yang bathil dan (janganlah) kamu membawa (urusan) harta itu kepada hakim, supaya kamu dapat memakan sebagian daripada harta benda orang lain itu dengan (jalan berbuat) dosa, padahal kamu mengetahui. (QS. al-Baqarah: 188) 
Hai orang-orang yang beriman, janganlah kamu saling memakan harta sesamamu dengan jalan yang bathil, kecuali dengan jalan perniagaan yang berlaku dengan suka sama suka di antara kamu. Dan janganlah kamu membunuh dirimu; sesungguhnya Allah adalah Maha Penyayang kepadamu. (QS. an-Nisa': 29)

Begitupun di dalam hadistnya, Rasulullah Saw telah melarang jual beli al-hashah dan jual beli gharar. Jual beli gharar menurut Imam as-Sa'adi termasuk dalam kategori perjudian yang sudah jelas keharamannya dalam nash al-Qur'an.

\section{Bentuk Gharar}

Ditinjau dari isi kandungannya, bentuk-bentuk transaksi gharar menurut Abdullah Muslih terbagi menjadi tiga bagian, yaitu:

1. Jual beli barang yang belum ada (ma'dum)

Tidak adanya kemampuan penjual untuk menyerahkan obyek akad pada waktu terjadi akad, baik obyek akad tersebut sudah ada ataupun belum ada (bai' al-ma'dum). Misalnya menjual janin yang masih dalam perut binatang ternak tanpa bermaksud menjual induknya, atau menjual janin dari janin binatang yang belum lahir dari induknya ( $h a b a l$ al-habalah), kecuali dengan cara ditimbang sekaligus atau setelah anak binatang itu lahir (HR. Abu Dawud). Contoh lain adalah menjual ikan yang masih di dalam laut atau burung yang masih di udara. Hal ini didasarkan atas hadist Rasulullah Saw, "Janganlah kamu menjual ikan yang masih di dalam air, karena itu adalah gharar". (HR. Ahmad bin Hambal). Demikian juga dengan menjual budak yang melarikan diri, harta rampasan perang yang belum dibagi, harta sedekah yang belum diterima, dan hasil menyelam yang di dalam air (HR. Ahmad bin Hambal dan Ibnu Majah).

2. Jual beli barang yang tidak jelas (Majhul)

a. Menjual sesuatu yang belum berada di bawah penguasaan penjual. Bila suatu barang belum diserahterimakan di saat jual beli, maka barang tersebut tidak dapat dijual kepada yang lain. Sesuatu/ barang jika belum diterima oleh si pembeli tidak boleh melakukan kesepakatan kepada yang lain untuk bertransaksi 
atau jual beli, karena wujud dari barang tersebut belum jelas, baik kriteria, bentuk dan sifatnya. Ketentuan ini didasarkan pada hadist yang menyatakan bahwa Rasulullah Saw melarang menjual barang yang sudah dibeli sebelum barang tersebut berada dibawah penguasaan pembeli pertama (HR. Abu Dawud). Karena dimungkinkan rusak atau hilang obyek dari akad tersebut, sehingga jual beli yang pertama dan yang kedua menjadi batal.

b. Tidak adanya kepastian tentang sifat tertentu dari benda yang dijual. Rasulullah Saw bersabda: "Janganlah kamu melakukan jual beli terhadap buah-buahan, sampai buah-buahan tersebut terlihat baik (layak konsumsi)" (HR. Ahmad bin Hambal, Muslim, anNasa'i, dan Ibnu Majah). Demikian juga larangan untuk menjual benang wol yang masih berupa bulu yang melekat pada tubuh binatang dan keju yang masih berupa susu (HR. ad-Daruqutni).

c. Tidak adanya kepastian tentang waktu penyerahan obyek akad. Jual beli yang dilakukan dengan tidak menyerahkan langsung barang sebagai obyek akad. Misalnya, jual beli dengan menyerahkan barang setelah kematian seseorang. Tampak bahwa jual beli seperti ini tidak diketahui secara pasti kapan barang tersebut akan diserahterimakan, karena waktu yang ditetapkan tidak jelas. Namun, jika waktunya ditentukan secara pasti dan disepakati antara keduanya maka jual beli tersebut adalah sah.

d. Tidak adanya kepastian obyek akad. Yaitu adanya dua obyek akad yang berbeda dalam satu transaksi. Misalnya, dalam suatu transaksi terdapat dua barang yang berbeda kriteria dan kualitasnya, kemudian ditawarkan tanpa menyebutkan barang yang mana yang akan di jual sebagai obyek akad. Jual beli ini merupakan suatu bentuk penafsiran atas larangan Rasulullah Saw untuk melakukan bai'atain fi bai'ah. Termasuk di dalam jual beli gharar adalah jual beli dengan cara melakukan undian dalam berbagai bentuknya (HR. al-Bukhari).

e. Kondisi obyek akad tidak dapat dijamin kesesuaiannya dengan yang ditentukan dalam transaksi. Misalnya, transaksi/ jual beli motor dalam kondisi rusak. Jual beli seperti ini salah satu bentuk 
dari gharar karena di dalamnya terkandung unsur spekulatif bagi penjual dan pembeli, sehingga sama halnya dengan melakukan jual beli undian.

3. Jual beli barang yang tidak mampu diserahterimakan.

a. Tidak adanya kepastian tentang jenis pembayaran atau jenis benda yang dijual. Wahbah az-Zuhaili berpendapat bahwa ketidakpastian tersebut merupakan salah satu bentuk gharar yang terbesar larangannya.

b. Tidak adanya kepastian tentang jumlah harga yang harus dibayar. Misalnya, penjual berkata: "Saya jual beras kepada anda sesuai dengan harga yang berlaku pada hari ini." Ketidakpastian yang terdapat dalam jual beli ini merupakan illat dari larangan melakukan jual beli terhadap buah-buahan yang belum layang dikonsumsi. Dasar hukumnya adalah hadist yang diriwayatkan oleh Ahmad bin Hambal, Muslim, an-Nasa'i, dan Ibnu Majah di atas.

c. Tidak adanya ketegasan bentuk transaksi, yaitu adanya dua macam atau lebih transaksi yang berbeda dalam satu obyek akad tanpa menegaskan bentuk transaksi mana yang dipilih sewaktu terjadi akad. Bentuk jual beli seperti ini merupakan larangan seperti halnya Rasulullah Saw melarang terhadap terjadinya dua jual beli/ transaksi dengan satu akad (bai'ataini fi bai'ah) (HR. Ahmad bin Hambal, an-Nasa'i, dan Tirmidzi). Misalnya, melakukan jual beli motor dengan harga Rp. 13 juta jika kontan/ tunai dan Rp. 20 juta jika pembeli melakukan pembayaran dengan cara kredit, namun ketika akad berlangsung dan terjadi kesepakatan tidak ditegaskan transaksi mana yang dipilih.

d. Adanya keterpaksaan. Antara lain berbentuk: (a). Jual beli lempar batu (bai al hasa), yaitu seseorang melempar batu pada sejumlah barang dan barang yang terkena batu tersebut wajib untuk dibelinya. Larangan terhadap jual beli tersebut berdasarkan hadist Rasulullah Saw, yang diriwayatkan oleh Abu Hurairah r.a: Rasulullah Saw melarang jual beli lempar batu dan jual beli yang mengandung tipuan."(HR. al-Jama'ah kecuali Bukhari). (b). Jual beli dengan saling melempar (bai' al-munabazah) yaitu 
seseorang melemparkan bajunya kepada orang lain dan jika orang yang dilemparkan tersebut melemparkan bajunya kepada yang melemparnya maka diantara keduanya wajib untuk melakukan jual beli, meskipun pembeli tidak tahu akan kualitas dari barang yang dibelinya. (c). Jual beli dengan cara menyentuh (bai' almulamasah), yaitu jika seseorang menyentuh suatu barang maka barang itu wajib dibelinya, meskipun ia belum mengetahui dengan jelas barang apa yang akan dibelinya.

\section{Gharar dalam Trnsaksi Ekonomi}

Transaksi perdagangan umumnya mengandung risiko untung dan rugi. Hal yang wajar bagi setiap orang berharap untuk selalu mendapatkan keuntungan, tapi belum tentu dalam setiap usahanya akan mendapatkan keuntungan. Menurut Imam Ghazali bahwa motivasi seorang pedagang adalah keuntungan, yaitu keuntungan di dunia dan keuntungan di akhirat. Risiko untung dan rugi merupakan kondisi yang tidak pasti dalam setiap usaha.

Dapat ditekankan bahwa Islam tidak melarang suatu akad yang hanya terkait dengan risiko atau ketidakpastian. Hanya bila risiko tersebut sebagai upaya untuk membuat satu pihak mendapatkan keuntungan atas pengorbanan pihak lain, maka hal tersebut menjadi gharar. Menurut Ibnu Taimiyah sudah jelas bahwa Allah Swt dan Rasulullah Saw tidak melarang setiap jenis risiko. Begitu juga tidak melarang semua jenis transaksi yang kemungkinan mendapatkan keuntungan atau kerugian ataupun netral (tidak untung dan tidak rugi). Yang dilarang dari kegiatan semacam itu ialah memakan harta orang lain secara tidak benar, bahkan bila tidak terdapat risiko, bukan risikonya yang dilarang.

Yang menjadikan gharar dilarang adalah karena keterkaitannya dengan memakan harta orang lain dengan cara tidak benar, jadi bukan semata-mata adanya unsur risiko, ketidakpastian ataupun disebut pula dengan game of chance. Karena hal ini akan mengakibatkan merugikan bagi pihak lain.

Masyarakat arab jahiliyah, biasa menyimpan tiga anak panah di dalam ka'bah yang dibalut dengan kertas putih yang bertuliskan lakukan, jangan 
lakukan, dan kosong. Sebelum mereka melakukan perjalanan jauh, misalnya, mereka kan pergi menemui juru kunci ka'bah dan meminta untuk diambilakn salah satu dari anak panah tersebut. Hal ini adalah merupakan salah satu bentuk game of chance yang primitive yaitu yang dilakukan tanpa usaha untuk membuat salah satu kemungkinan hasil yang diinginkan yang keluar.

Game of chance yang diupayakan kemenangannya, disebut game of skill (permainan ketangkasan). Misalnya bila kalah dalam permainan sepak bola, maka akan pergi jauh dari daerahnya. Hal inipun termasuk kategori game of chance. Jadi yang menentukan boleh atau tidaknya bukan apakah game of chance dilakukan dengan usaha atau tanpa usaha. Yang menentukan adalah apakah hasil dari game of chance tersebut menentukan tindakan yang akan diambil selanjutnya, atau dengan kata lain menggantungkan nasib kepada hasil dari game of chance tersebut.

Game of chance yang kita menggantungkan nasib pada hasilnya dan salah satu pihak harus menanggung beban pihak lain akibat hasil dari game of chance tersebut, disebut maisir.

Ketidakpastian bukanlah spekulatif, begitu pula game of chance bukanlah perjudian. Hanya bila suatu tindakan bergantung pada hasil usaha game of chance, ia termasuk mengundi nasib dengan anak panah (QS. An-Nisa': 90) dan oleh karenanya terlarang. Hanya bila suatu tindakan bergantung pada hasil game of chance dan salah satu pihak harus menanggung beban pihak lain akibat dari hasil game of chance, maka ia termasuk kategori maisir dan oleh karenanya terlarang.

Dalam transaksi modern, banyak ditemukan model transaksi yang termasuk dalam kategori gharar. Terutama transaksi yang dilakukan oleh lembaga keuangan. Umum terjadi, lembaga keuangan modern merupakan lembaga usaha yang bertujuan untuk mendapatkan keuntungan. Gharar dalam lembaga keuangan modern terdapat pada cara mereka melakukan usaha dan mendapatkan keuntungan.

\section{Perbankan}

Lembaga perbankan merupakan pilar dari ekonomi modern. Hingga tingkat kemajuan dari perbankan mampu mempengaruhi kondisi ekonomi suatu 
bangsa. Berkembang atau tidaknya suatu kondisi ekonomi dapat dilihat dari perkembangan perbankan. Namun, ditilik dari syariat Islam, lembaga perbankan umum yang telah berkembang sarat dengan unsur-unsur gharar, maisir dan riba, yang jelas dilarang dalam aturan syariat Islam.

Gharar dalam perbankan dapat dilihat dari sistem bunga yang dibebankan pada setiap transaksi, baik dalam transaksi pinjaman maupun simpanan. Beban bunga yang ditetapkan adalah merupakan jenis gharar yang mempertukarkan kewajiban antara satu pihak dengan pihak yang lain. Contoh, disaat melakukan pengajuan pinjaman pada bank untuk suatu usaha dengan beban bunga sebesar 10\%. Jika usaha yang dilakukan mendapat keuntungan $100 \%$ atau lebih, maka pihak peminjam akan untung, karena hanya membayar bunga sebesar 10\%. Sedangkan bila usaha mengalami kerugian maka akan ditanggung sendiri, dan pihak bank tidak akan peduli dengan kondisi tersebut, saat masa jatuh tempo pihak peminjam harus mengembalikan dana pinjamannya beserta bunga yang dibebankan, ibarat sudah jatuh tertimpa tangga. Jadi risikolah yang dipertukarkan.

\section{Asuransi}

Asuransi merupakan bentuk pertanggungan yang dilakukan antara satu pihak dengan pihak lain. Dalam Undang-undang RI No. 2 Tahun 1992 Tentang Usaha Perasuransian, Asuransi atau pertanggungan merupakan perjanjian antara dua pihak atau lebih, dimana pihak penanggung mengikatkan diri kepada tertanggung, dengan menerima premi asuransi, untuk memberikan penggantian kepada tertanggung karena kerugian, kerusakan, atau kehilangan keuntungan yang diharapkan. Atau, tanggung jawab hukum kepada pihak ketiga yang mungkin akan diderita tertanggung, yang timbul dari suatu peristiwa yang tidak pasti; atau untuk memberikan pembayaran yang didasarkan atas meninggal atau hidupnya seseorang yang dipertanggungkan.

Gharar terjadi dalam asuransi apabila kedua belah pihak (misalnya: peserta asuransi, pemegang polis, dan perusahaan) saling tidak mengetahui apa yang akan terjadi, kapan musibah akan menimpa. Kontrak yang dilakukan pada kondisi tersebut adalah suatu kontrak yang dibuat berasaskan pada pengandaian (ihtimal) semata. Hal inilah yang disebut 
gharar 'ketidakjelasan' yang dilarang dalam syariat Islam. Karena bentuk dari kontrak tersebut akan mengakibatkan terjadinya saling mendzalimi.

Meskipun kedua belah pihak saling meridhoi, kontrak tersebut secara dzatnya tetap termasuk dalam kategori gharar yang diharamkan. Walupun nisbah/ persentase atau kadar bayarannya telah ditentukan agar peserta asuransi/ pemegang polis maklum, ia tetap tidak tahu kapan musibah akan terjadi, disinilah gharar terjadi.

Secara konvensional, kontrak/ perjanjian dalam asuransi jiwa dapat dikategorikan sebagai akad tabaduli atau akad pertukaran, yaitu pertukaran pembayaran premi dengan uang pertanggungan. Secara syariah, dalam akad pertukaran harus jelas berapa yang dibayarkan dan berapa yang harus diterima. Keadaan ini akan menjadi rancu (gharar) karena kita tahu berapa yang akan diterima (sejumlah uang petanggungan), tetapi tidak tahu berapa yang akan dibayarkan (jumlah seluruh premi). Disinilah terjadinya gharar pada asuransi konvensional.

Gambaran dari bentuk gharar tersebut adalah jika seseorang mengambil paket asuransi 10 tahun dengan besar uang pertanggungan misalnya 10 juta. Apabila pada tahun keempat orang yang bersangkutan meninggal dan baru bayar premi sebesar 4 juta, maka ahli warisnya mendapatkan jumlah yang penuh 10 juta. Pertanyaan yang muncul, dari mana sisa 6 juta diperoleh. Uang 6 juta yang di dapat ahli waris tersebut merupakan bentuk gharar.

\section{Bursa Saham}

Bursa saham adalah pasar yang di dalamnya berjalan usaha jual beli saham. Target bursa adalah menciptakan pasar simultan dan kontinyu dimana penawaran dan permintaan serta orang-orang yang hendak melakukan perjanjian jual beli dipertemukan. Tentunya dalam hal ini akan mendapatkan berbagai keuntungan bagi pihak pelaku.

Dalam bursa saham, bentuk gharar banyak ditemukan dalam setiap transaksinya. Adapun gharar tersebut dapat terjadi disebabkan oleh:

a. Transaksi berjangka dalam pasar saham sebagian besar bukanlah jual beli sesungguhnya. Karena tidak ada unsur serah terima dalam pasar saham ini antara kedua belah pihak yang bertransaksi, padahal 
syarat jual beli adalah adanya serah terima barang dagangan dan pembayarannya atau salah satu dari keduanya.

b. Kebanyakan penjualan dalam pasar ini adalah penjualan sesuatu yang tidak dimiliki, baik itu berupa mata uang, saham, giro piutang, atau barang komoditi komersial dengan harapan akan dibeli di pasar sesungguhnya dan diserahterimakan pada saatnya nanti, tanpa mengambil uang pembayaran terlebih dahulu pada waktu transaksi sebagaimana syaratnya jual beli.

c. Pembeli dalam pasar ini kebanyakan membeli menjual kembali barang yang dibelinya sebelum ia terima. Orang kedua akan menjual kembali sebelum dia terima. Hal semacam ini terjadi secara berulang-ulang, terhadap obyek jualan yang belum diterima, hingga transaksi itu berkhir pada pembeli sebenarnya, atau paling tidak menetapkan harga sesuai pada hari pelaksanaan transaksi, yaitu hari penutupan harga.

d. Yang dilakukan oleh pemodal besar dengan memonopoli saham sejenisnya serta barang-barang komoditi komersial lain dipasaran agar bisa menekan pihak penjual yang menjual barang-barang yang tidak mereka miliki dengan harapan akan membelinya pada saat transaksi dengan harga yang lebih murah, atau langsung melakukan serah terima sehingga menyebabkan para penjual lain merasa kesulitan.

e. Dalam pasar modal dijadikannya pasar ini sebagai pemberi pengaruh pasar dengan skala lebih besar. Karena harga-harga dalam pasar ini tidak sepenuhnya bersandar pada mekanisme pasar semata secara prkatis dari pihak orang-orang yang butuh jual beli. Namun justru terpengaruh oleh banyak hal, sebagian diantaranya dilakukan oleh para pemerhati pasar, sebagian lagi dari adanya monopoli barang dagangan dan kertas saham, atau dengan menyeberkan berita bohong dan sejenisnya. Cara-cara yang dilakukan dapat menyebabkan ketidakstabilan harga secara tidak alami, sehingga dapat berpengaruh buruk terhadap perekonomian.

\section{Penutup}

Kondisi ekonomi yang ditopang dengan lembaga keuangan konvensional, banyak mengandung unsur gharar yang jelas telah dilarang dalam syariat 
Islam. Jelas bahwa Islam memiliki batasan yang tegas terhadap berbagai transaksi ekonomi, sehingga jelas mana yang dilarang atau tidak dilarang. Dan hal ini menjadi tuntunan bagi umat Islam dalam melaksanakan kegiatan ekonominya. Nilai-nilai keadilan merupakan hal utama yang menjadi prinsip pokok untuk melandasi kegiatan ekonomi. Adil yang dimaksud adalah tidak menyebabkan kerugian di salah satu pihak, sehingga merasa teraniaya oleh pihak yang lain.

\section{Pustaka Acuan}

Dahlan, Abdul Azis, et.al, Ensiklopedi Hukum Islam, Jakarta, Ichtar BAru Van Hoeve, 1996

Karim, Adiwarman, Ekonomi Mikro Islam, Jakarta, IIT Indonesia, 2003

Muslih, Abdullah, Fikih Ekonomi Keuangan Islam, Jakarta, Darul Haq, 2004

Sula, M. Syakir, Asuransi Syariah, konsep dan sistem operasional, Jakarta, Gema Insani, 2004

http//www.republika.co.id//jual beli gharar, Jum'at, 16 Maret 2007 